\title{
Density, vertical distribution and trophic responses of metazoan meiobenthos to phytoplankton deposition in contrasting sediment types
}

\author{
M. A. Franco ${ }^{1,3}$, K. Soetaert ${ }^{2}$, D. Van Oevelen ${ }^{2}$, D. Van Gansbeke ${ }^{1}$, M. J. Costa ${ }^{3}$, \\ M. Vincx ${ }^{1}$, J. Vanaverbeke ${ }^{1, *}$ \\ ${ }^{1}$ Marine Biology Section, Biology Department, Ghent University, Krijgslaan 281 (S8), 9000 Ghent, Belgium \\ ${ }^{2}$ NIOO-KNAW Centre for Estuarine and Marine Ecology, Korringaweg 7, 4401 NT Yerseke, Netherlands \\ ${ }^{3}$ Oceanography Institute, Faculty of Sciences, University of Lisbon, Campo Grande, 1749-016 Lisboa, Portugal
}

\begin{abstract}
We investigated meiobenthic community response (as density and vertical distribution) to the sedimentation of phytoplankton in 2 contrasting sites in the southern North Sea, one with fine grained sediment close to the coastline and another with highly permeable sediments. Meiobenthic densities and pigments in the water column and sediment were measured monthly from October 2002 until October 2003. Stable isotope ${ }^{13} \mathrm{C}$ and ${ }^{15} \mathrm{~N}$ signatures were analysed in sediment particulate organic matter (POM), water suspended particulate matter (SPM) and in different meiobenthic taxa at 3 different times (prior, during and after spring bloom deposition) at 2 sediment depths (0 to 1 and 4 to $5 \mathrm{~cm}$ ). Our aim was to determine whether sediment type affects the overall meiobenthic community response (densities and vertical distribution) and utilisation of freshly deposited phytoplankton as a food source. Variation in nematode response to the sedimentation event was evident and was related to the contrasting biogeochemical processes at the stations. In permeable sediments, the nematode response was rapid after phytoplankton deposition, while in the fine-grained station, nematode response (as density) was delayed. In general, meiobenthic ${ }^{13} \mathrm{C}$ signatures remained relatively constant over time and were not coupled with changes in water SPM and sediment POM. There was vertical variation in meiobenthic ${ }^{13} \mathrm{C}$ signatures in fine sediments. Nematodes belonging to the genera Sabatieria and Richtersia from the deeper sediment layer had isotope signatures similar to those of surface living nematodes, indicating migration of these genera to the surface to feed. In permeable sediments, such vertical differences were absent because of sediment biogeochemical properties. $\delta^{13} \mathrm{C}$ and $\delta^{15} \mathrm{~N}$ values of copepods clearly indicated a chemoautotrophic food source within the fine-grained sediment, which has not been previously reported for these environments.
\end{abstract}

KEY WORDS: Stable isotopes $\cdot$ Meiobenthos $\cdot$ North Sea $\cdot$ Phytoplankton bloom Resale or republication not permitted without written consent of the publisher

\section{INTRODUCTION}

In marine environments, benthic communities below the euphotic zone are supported by primary production from pelagic or benthic photic areas, with a few exceptions such as hot vents and cold seeps. The magnitude of this supply of organic matter (OM) is determined by temporal and spatial patterns. Phytoplankton bloom sedimentation events represent a major source of OM for the benthic system where it fuels benthic life (Graf 1992). Moreover, the source and nature of the organic material settling on the substratum are important for benthic dynamics. Also, the fate of the organic material that reaches the sea floor is dependent on the nature of the sediment (Graf 1992).

In fine-grained depositional sites, sharp vertical profiles of labile OM (measured as chlorophyll a concentrations) can emerge after the sedimentation of 
phytoplankton blooms (e.g. Franco et al. 2007). Mineralisation of this newly-arrived carbon often creates oxygen stress (Graf 1992) and breakdown of this OM can be retarded (Boon \& Duineveld 1998, P. Provoost et al. unpubl. data). In coarser permeable sediments, these sharp vertical gradients may be absent and subsurface peaks of chl a are regularly reported (e.g. Ehrenhauss \& Huettel 2004, Vanaverbeke et al. 2004b). Degradation of OM within these sediments is often rapid (Vanaverbeke et al. 2004b, Bühring et al. 2006). The different biogeochemical conditions in such contrasting sediments affect the responses of the resident bacterial (Franco et al. 2007) and nematode communities (Steyaert 2003, Vanaverbeke et al. 2004a,b). After phytoplankton sedimentation, nematode communities have variable response times (delayed in fine-grained sediments versus fast in permeable sediments) and variable diversity patterns (no change in fine-grained sediments versus increased in permeable sediments). In addition, an aberrant nematode morphotype (the stout and short nematodes defined by Vanaverbeke et al. 2004a) react opportunistically to phytoplankton sedimentation in permeable sediments (Vanaverbeke et al. 2004a), while this has not been observed at depositional stations. Nematode density responses are depth- and species-specific in fine-grained sediment (Steyaert 2003), while this is not the case in permeable sediments. Our hypothesis was that all these patterns are related to the quality and quantity of available food sources and the ability of nematodes to feed on particular food items (Moens \& Vincx 1997).

In this paper we take a closer look at nematode community dynamics at 2 sites with contrasting sediments in the North Sea. Both stations have been studied in detail (Steyaert 2003, Vanaverbeke et al. 2004a,b). The earlier studies suggest that meiobenthic responses to phytoplankton sedimentation may vary by sediment biogeochemical characteristics. Our aim was to: (1) investigate the overall community response (densities and vertical distributions) to the spring phytoplankton bloom deposition in 2 sediment types, and (2) use stable isotope analysis to determine how freshly deposited phytodetritus is exploited by nematodes in 2 sediment types. Carbon $\left({ }^{13} \mathrm{C}\right)$ and nitrogen $\left({ }^{15} \mathrm{~N}\right)$ stable isotope signatures provide powerful tools for estimating carbon flows to consumers and for determining their respective trophic positions in food webs (see Post 2002). Dual stable isotopic signatures of nematodes have mostly been reported at the community level (e.g. Riera et al. 1996, Riera \& Hubas 2003) and detailed studies determining the food source of different nematode taxa are still rare (Carman \& Fry 2002, Moens et al. 2005). Studies including other meiobenthic taxa (e.g. meiobenthic polychaetes, Halacaroidea and harpacticoid copepods) are also rare (Couch 1989, Carman \& Fry 2002). Therefore, little is known about possible competition for food sources within the meiobenthos. Furthermore, there is little known about how meiobenthic organisms are able to exploit the gradient (Graf 1992) from high quality fresh food at the sediment-water interface to older food sources of lesser quality deeper down in the sediment (Rudnick 1989, Widbom \& Frithsen 1995). We compared $\delta^{13} \mathrm{C}$ and $\delta^{15} \mathrm{~N}$ signatures in nematodes (genus or group level) and other meiobenthic taxa, and in sediment particulate organic matter (POM) and suspended particulate matter (SPM) to clarify nematode assemblage responses to the spring phytoplankton bloom deposition on different sediment types. The null hypotheses tested were (1) there would be no differences in nematode vertical distribution among sampling times within stations, (2) there would be no differences in isotopic signals of the food sources and meiobenthic organisms among sampling dates or among sediment depths, and (3) there would be no differences in isotopic signals among meiobenthic taxa or nematode groups within stations.

\section{MATERIALS AND METHODS}

Study site and sampling. Samples were taken from the Belgian Continental Shelf (BCS) Stns 115bis (close to the coast, $51^{\circ} 09.2^{\prime} \mathrm{N}, 02^{\circ} 37.2^{\prime} \mathrm{E} ; 13 \mathrm{~m}$ depth) and 330 (further offshore, $51^{\circ} 26.0^{\prime} \mathrm{N} 02^{\circ} 48.5^{\prime} \mathrm{E}$; $20 \mathrm{~m}$ depth) (Fig. 1).

Stn 115bis is a depositional station characterised by the presence of fine sediments (mean grain size: $185 \mu \mathrm{m})$ with a small fraction of mud (4\%) (Steyaert 2003), while Stn 330 consists of medium sand (mean grain size: $329-361 \mu \mathrm{m}$ ) without mud (Vanaverbeke et al. 2004a,b) and highly permeable sediments.

Sampling at the stations was conducted monthly from October 2002 until October 2003 from the vessels RV 'Zeeleeuw' or 'Belgica'. Stn 330 was not sampled in December 2002 due to bad weather and rough seas.

The water column was sampled $3 \mathrm{~m}$ below the airsea interface and $1 \mathrm{~m}$ above the sea floor using $10 \mathrm{l}$ Niskin bottles. Pigment samples were collected by filtering $500 \mathrm{ml}$ of water from each depth onto GF/F glass microfibre filters (i.d. $4.7 \mathrm{~cm}$ ) using a vacuum pump. This procedure was repeated 3 times. The samples were kept in the dark, preserved at $-20^{\circ} \mathrm{C}$ on board and stored at $-80^{\circ} \mathrm{C}$ in the laboratory.

Sediment was sampled using a Reineck box corer (surface area $180 \mathrm{~cm}^{2}$ ) or another box corer with a larger surface area (February, April and October 2003 cruises). The box corer was deployed three times at each sampling station. In February only two box corer samples were taken from Stn 330. 


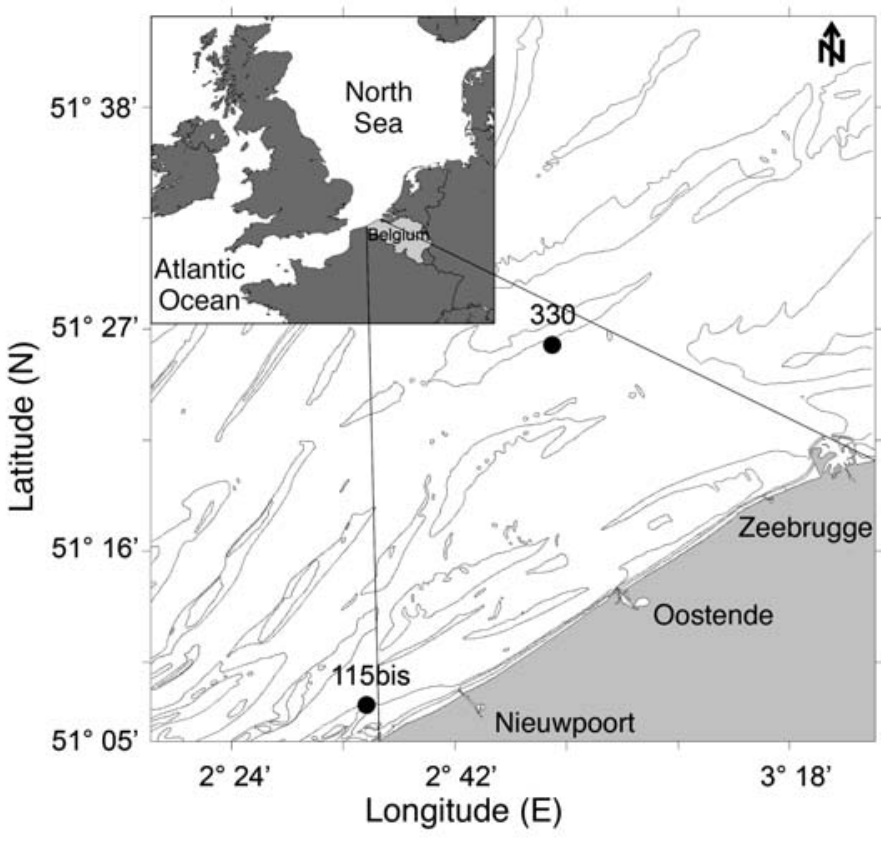

Fig. 1. Location of sampling Stns $115 \mathrm{bis}$ and 330 on the Belgian Continental Shelf

From each box corer, 2 acrylic plastic cores (i.d. $3.6 \mathrm{~cm})$ were taken, 1 for meiobenthos and 1 for pigment analysis. These cores were sliced in $1 \mathrm{~cm}$ slices to a maximum depth of $10 \mathrm{~cm}$. Samples for pigment analysis were preserved at $-20^{\circ} \mathrm{C}$ on board and stored at $-80^{\circ} \mathrm{C}$ in the laboratory. The meiobenthos samples were preserved in a hot $\left(70^{\circ} \mathrm{C}\right)$, neutral formaldehyde tap-water solution.

During 3 detailed sampling cruises (February, April and October 2003), 3 extra cores were taken on each sampling occasion at each station for studying carbon and nitrogen stable isotope signatures in sediment and meiobenthos. Samples were kept frozen at $-20^{\circ} \mathrm{C}$ until further processing. For the stable isotope signatures in the SPM, the water column $1 \mathrm{~m}$ above the sea floor was sampled and filtered as described above.

Laboratory treatment of samples. The sediment samples for pigment analysis were weighed and chl a concentrations in the sediment were determined by HPLC (Gilson) following Wright \& Jeffrey (1997).

Meiobenthos (animals passing through a $1 \mathrm{~mm}$ sieve and retained on a $38 \mu \mathrm{m}$ sieve) was extracted from the sediment by centrifugation in a LUDOX HS-40 solution (Heip et al. 1985). After staining with Rose Bengal, all organisms were counted and sorted into higher taxa under a binocular microscope.

Stable isotope analysis. Each meiobenthic sample (3 replicates per sampling occasion at both stations) was unfrozen and the specimens were picked out with a fine needle under a binocular microscope. The organisms were rinsed, initially in $0.2 \mu \mathrm{m}$-filtered sea- water, then in $0.2 \mu \mathrm{m}$-filtered Milli-Q water to remove adhering particles, and transferred to tin capsules. The capsules were oven dried, pinched closed and stored $\left(-20^{\circ} \mathrm{C}\right)$ until further analysis. The procedure was repeated with 10 empty capsules to obtain blank values ( 5 for carbon and 5 for nitrogen).

About 60 and 160 nematodes were picked out from each capsule for ${ }^{13} \mathrm{C}$ and ${ }^{15} \mathrm{~N}$ analyses, respectively. The taxonomic resolution of the samples taken for stable isotope signatures depended on the number of nematodes present. When sufficient numbers were available from the samples at Stn 330, 'stout nematodes' (as defined by Vanaverbeke et al. 2004a) were picked out separately from the rest of the nematodes. Other meiobenthic taxa (copepods, Halacaroidea, polychaetes) were also picked out separately. Nematodes from the genera Sabatieria and Richtersia (also a stout nematode) were picked out separately from the other nematodes at Stn 115bis. When densities were insufficient to analyse a specific group of nematodes or a specific meiobenthic taxon separately, these groups were included in the bulk nematode or meiobenthic sample. Replicates for all groups were not always obtained due to low abundances of nematodes. For the same reason, it was not always possible to estimate the $\delta^{15} \mathrm{~N}$ of stout nematodes at Stn 330 .

Stable isotope ratios of sediment POM, SPM (filters) and meiobenthos were measured by elemental analyser-isotope ratio mass spectrometry (EA-IRMS) (Middelburg et al. 2000). Data are expressed in standard $\delta$-unit notation:

$$
\delta \mathrm{X}=\left[\left(R_{\text {sample }} / R_{\text {reference }}\right)-1\right] \times 10^{3}
$$

where $R_{\text {sample }}$ is either the ${ }^{13} \mathrm{C}:{ }^{12} \mathrm{C}$ ratio or the ${ }^{15} \mathrm{~N}:{ }^{14} \mathrm{~N}$ ratio in the sample and $R_{\text {reference }}$ is the isotope ratio of the reference material. These ratios are reported as \%o deviations from standards, viz. the carbon isotope ratio of Vienna Pee Dee Belemnite $\left(R_{\mathrm{VPDB}}=0.0112372\right)$ and the nitrogen isotope ratio of air $\mathrm{N}_{2}\left(R_{\mathrm{AIR}}=0.0036765\right)$. As trophic fractionation is low for carbon isotopes (mean $=0.4 \%, \mathrm{SD}=1.3 \%$ ) and high for $\delta^{15} \mathrm{~N}$ (mean $=$ $3.4 \%$, $\mathrm{SD}=1 \%$ ) , a consumer will have a $\delta^{13} \mathrm{C}$ value similar to its food source, whilst the $\delta^{15} \mathrm{~N}$ value will be enriched by, on average, $3.4 \%$ relative to the food source (Post 2002).

Data analysis. Spearman rank correlation tests were used to investigate the correlation between the nematode densities and the chl a concentration in the sediment. Changes in nematode densities over time, sediment depth and time $\times$ depth were tested by constructing a univariate split-plot ANOVA design following Steyaert et al. (2001). Replicates were nested within time, but not within depth. This analysis was performed on both the whole sediment column ( 0 to $10 \mathrm{~cm}$ ) and on only the upper $5 \mathrm{~cm}$, since changes in 
quantity and quality of OM were most evident there (P. Provoost et al. unpubl. data; present study) as was the response of the nematodes communities at Stn 115bis in a previous study (Steyaert 2003). Variation in the ${ }^{13} \mathrm{C}$ signal of sediment POM by time, depth and time $\times$ depth was analysed using a 2-way ANOVA. Since it was not possible to obtain homogeneity of variances for $\delta^{13} \mathrm{C}$ and $\delta^{15} \mathrm{~N}$ values of meiobenthos, KruskalWallis (ANOVA by ranks) tests were conducted to test for differences between the meiobenthic taxa, sediment depth and sampling dates. All tests were performed using the STATISTICA 6 software package.

\section{RESULTS}

\section{Environmental variables}

Chl a concentrations in the water column at both stations started rising in February, peaked in April (48 $\mathrm{mg} \mathrm{m}^{-3}$ at Stn 115bis and $32 \mathrm{mg} \mathrm{m}^{-3}$ at Stn 330) and decreased afterwards (Fig. 2). Smaller peaks were also observed in July for both stations and in September only at Stn 330, reaching values no higher than $17 \mathrm{mg}$ $\mathrm{m}^{-3}$. The sediment $\mathrm{chl}$ a concentrations were about 5 times higher at Stn 115bis (Fig 3) than at Stn 330 (Fig. 4) throughout the sampling period and generally followed the patterns observed in the water column. At both stations, peak values were observed in April. At Stn 330, other peaks were observed in August 2003 and October 2003 reflecting the deposition of the late summer and autumn blooms (Fig. 4).

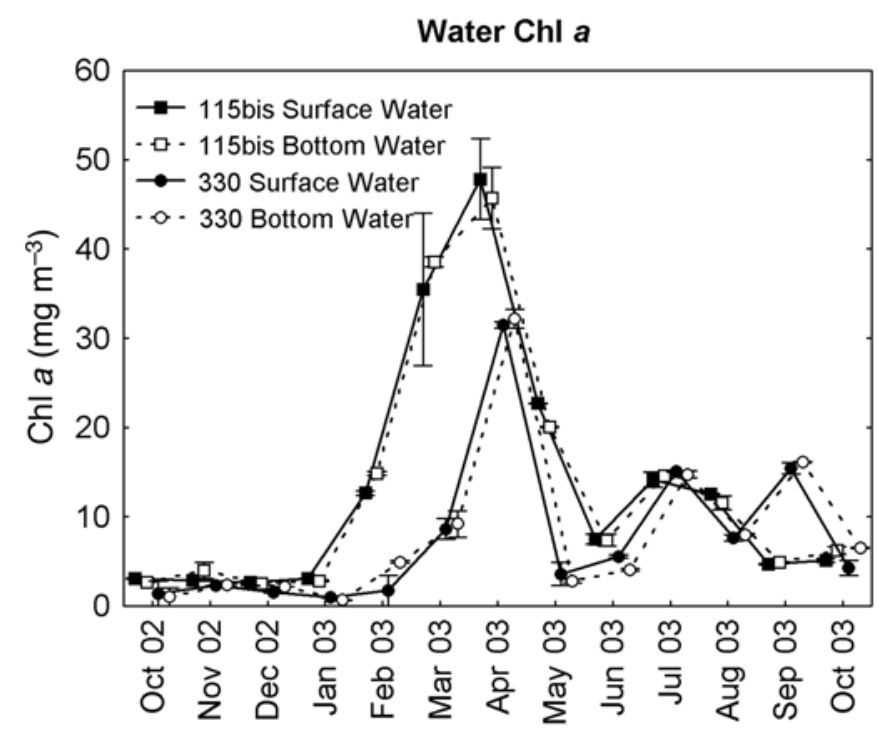

Fig. 2. Chl a concentration in the surface and bottom water $\left(\mathrm{mg} \mathrm{m}^{-3}\right)$ at Stns 115bis and 330 for the period from October 2002 to October 2003. See Fig. 1 for sampling station locations. Means $\pm \mathrm{SE}$
At Stn 115bis, chl a concentration in the sediment was highest near the sediment surface and decreased with sediment depth, especially after deposition of phytodetritus in April (Fig. 3). Except for October 2003, this gradient was not observed at Stn 330. In most cases, there was no clear vertical gradient in chl a vertical distribution (until March 2003), while in the second half of the study period, only minor differences between surface and deeper chl a concentrations occurred (ca. 100 to $200 \mathrm{ng} \mathrm{cm}{ }^{-3}$ ) (Fig. 4).

\section{Temporal patterns in meiobenthic densities}

In total, 12 meiobenthic taxa were found (Nematoda, harpacticoid Copepoda and nauplii, Cumacea, Gastrotricha, Halacaroidea, Kinorhyncha, Oligochaeta, Ostracoda, Polychaeta, Tardigrada and Turbellaria) among which only Cumacea was never observed at Stn 330 .

At Stn 115bis, Nematoda were highly numerically dominant, with an average representation of $96 \%$. Nematodes also dominated at Stn 330, but made up a considerably lower proportion (64\%). Here, other taxa were present with relatively high representation; harpacticoid Copepoda and nauplii represented 15\% and $11 \%$ of the meiobenthos, respectively.

At Stn 115bis, nematode densities were lowest in winter (1251 ind. $10 \mathrm{~cm}^{-2}$ in December) and increased towards April (4841 ind. $10 \mathrm{~cm}^{-2}$ ) (Fig. 5). No clear changes were observed in the following months until densities increased to highest values in September and October 2003 (7385 ind. $10 \mathrm{~cm}^{-2}$ in October). Nematode densities were not correlated with chl $a$ in the sediment $(r=0.30, p=0.067)$. The bulk of the nematode community was found in the upper $4 \mathrm{~cm}$ of the sediment column for most of the year, except for October 2003 when relatively high densities (804 ind. $10 \mathrm{~cm}^{-2}$ ) were found down to $7 \mathrm{~cm}$ depth (Fig. 5). From June until September, higher densities were also found in the 9 to $10 \mathrm{~cm}$ layer.

Nematodes densities in the top 5 sediment layers at Stn 115bis were not significantly affected by time $\left(F_{2,4}=0.59, \mathrm{p}=0.59\right)$, by sediment depth $\left(F_{4,8}=1.56\right.$, $\mathrm{p}=0.27)$ nor by the interaction of time and depth $\left(F_{8,16}=0.97, \mathrm{p}=0.48\right)$. When including the upper $10 \mathrm{~cm}$ in the analysis, a significant effect for depth was observed $\left(F_{9,18}=7.35, \mathrm{p}=0.0002\right)$, while this was not the case for time $\left(F_{2,4}=0.87, \mathrm{p}=0.487\right)$ or the interaction $\operatorname{term}\left(F_{18,36}=1.19, \mathrm{p}=0.319\right)$.

Nematode densities at Stn 330 were much lower than at Stn 115bis. Lowest values were recorded in November (349 ind. $10 \mathrm{~cm}^{-2}$ ), followed by a spring peak in May (1310 ind. $10 \mathrm{~cm}^{-2}$ ) (Fig. 6). Densities decreased towards July and increased again in August 
A
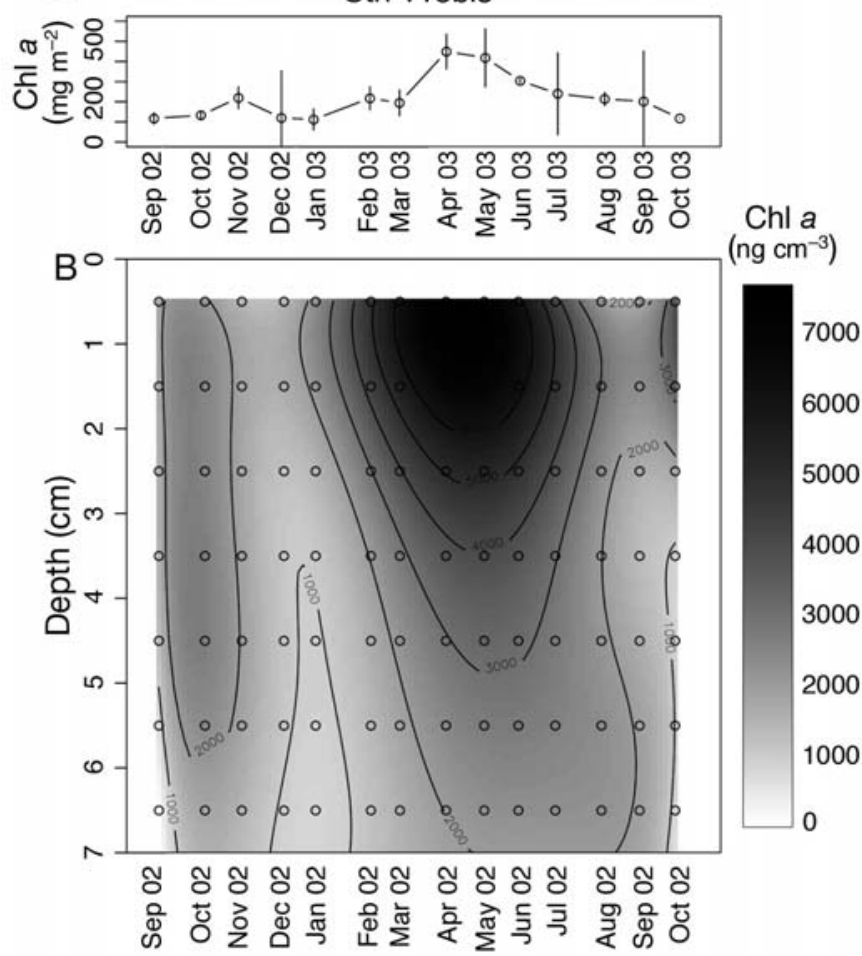

Fig 3. Stn 115bis. (A) chl a concentrations in the sediment $\left(\mathrm{mg} \mathrm{m}^{-2}\right)$ in the whole vertical profile from September 2002 to October 2003, means $\pm \mathrm{SE}_{\text {; }}$ (B) chl a concentrations in the sediment $\left(\mathrm{ng} \mathrm{cm}^{-3}\right)$ from 0 to $7 \mathrm{~cm}$ depth over the same time period

and October; highest values were observed in October 2003 (1989 ind. $10 \mathrm{~cm}^{-2}$ ). At Stn 330, nematode densities were correlated with chl $a$ in the sediment $(r=0.36$, $\mathrm{p}=0.033$ ). Subsurface maximum values were common, especially in October 2003 when densities were highest (Fig. 6). The "split-plot" ANOVA revealed that time $\left(F_{2,4}=23.78, \mathrm{p}=0.006\right)$, sediment depth $\left(F_{4,8}=4.14\right.$, $\mathrm{p}=0.041)$ and their interaction (time $\times$ depth, $F_{8,16}=$ $2.64, p=0.046)$ significantly affected the nematode densities. A second analysis including all sediment layers $(0$ to $10 \mathrm{~cm})$ showed that densities per sediment layer were significantly different between sampling events $\left(F_{2,4}=10.29, \mathrm{p}=0.027\right)$ and sediment depths $\left(F_{9,18}=3.36, \mathrm{p}=0.014\right)$. However, the effect of their interaction was not significant $\left(F_{18,36}=1.53, \mathrm{p}=\right.$ 0.136).

\section{Carbon and nitrogen stable isotope signatures}

At Stn 115 bis, sediment POM $\delta^{13} \mathrm{C}$ values were similar to the SPM $\delta^{13} \mathrm{C}$ values. Sediment POM $\delta^{13} \mathrm{C}$ values differed by sediment depth $\left(F_{1,12}=5.34, \mathrm{p}=0.039\right)$ and

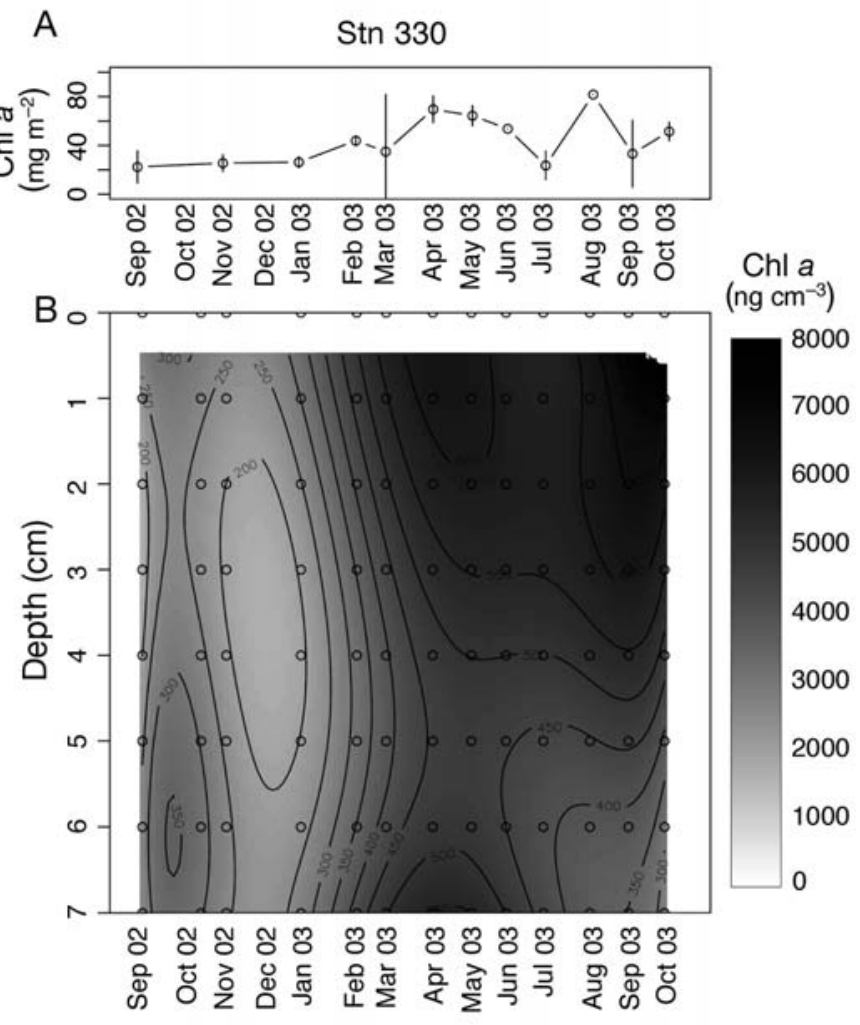

Fig. 4. Stn 330. (A) chl a concentrations in the sediment $\left(\mathrm{mg} \mathrm{m}^{-2}\right)$ in the whole vertical profile from September 2002 to October 2003, means $\pm \mathrm{SE}$; (B) chl a concentrations in the sediment $\left(\mathrm{ng} \mathrm{cm}^{-3}\right)$ from 0 to $7 \mathrm{~cm}$ depth over the same time period

sampling date $\left(F_{2,12}=15.53, \mathrm{p}=0.0005\right)$ (Fig. 7). Most depleted values $(\approx-22 \%$ ) occurred in February in both sediment layers ( 0 to 1 and 4 to $5 \mathrm{~cm}$ ). In April, values increased slightly and this increase was more prominent in the uppermost centimetre of sediment. Sediment POM $\delta^{13} \mathrm{C}$ values in October were similar in both layers and resembled the values for April in the surface layer.

Vertical differences in nematode isotopic signatures also occurred. Before sedimentation of the phytoplankton bloom, surface-dwelling nematodes were about $3 \%$ enriched compared to the corresponding OM signatures. Sabatieria spp. and Richtersia spp. had similar values when sampled in the 4 to $5 \mathrm{~cm}$ layer. Deeper-dwelling 'other nematodes' were more depleted (Fig. 7). In April, all surface-living nematodes and Sabatieria from the deeper sediment horizon had $\delta^{13} \mathrm{C}$ values slightly above or equal to the OM values. Deeper-dwelling 'other nematodes' were more depleted. A similar pattern occurred in October for Sabatieria and Richtersia, while 'other nematodes' in both sediment layers had more depleted values than the OM signal. Very depleted values for ${ }^{13} \mathrm{C}$ (average 


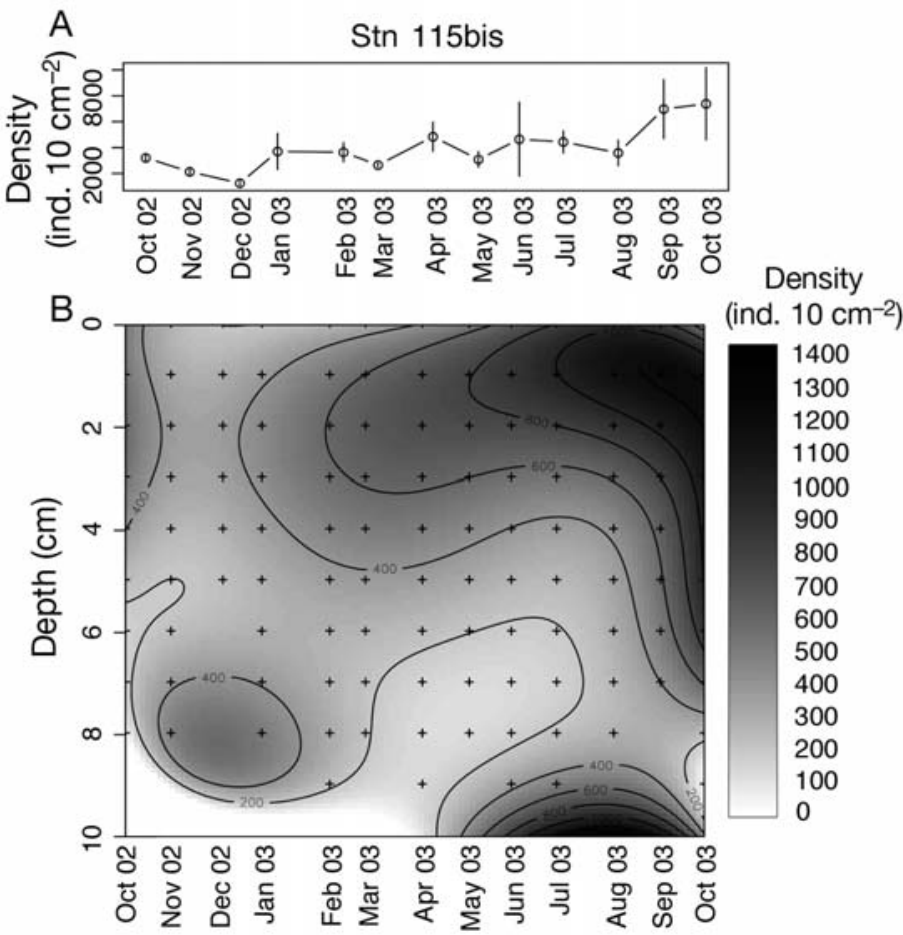

Fig. 5. Stn 115bis. (A) nematode densities (ind. $10 \mathrm{~cm}^{-2}$ ) from October 2002 to October 2003 summed over the vertical profile, means $\pm \mathrm{SE}_{\text {; }}(\mathrm{B})$ total nematode densities (ind. $10 \mathrm{~cm}^{-2}$ ) from 0 to $10 \mathrm{~cm}$ depth over the same time period

value -38.53 and $-38.54 \%$ ) and ${ }^{15} \mathrm{~N}(0.30$ and $1.27 \%)$ occurred in surface-living harpacticoid copepods in October.

At Stn $330, \delta^{13} \mathrm{C}$ values of sediment POM did not follow the $\delta^{13} \mathrm{C}$ isotope values of SPM (Fig. 8). The $\delta^{13} \mathrm{C}$ values of sediment OM differed significantly between sampling dates $\left(F_{2,10}=32.15, \mathrm{p}=0.00004\right)$ (Fig. 8).

More enriched values occurred in both sediment layers in October than in February and April. During February and April, all benthic groups from both sediment layers had average $\delta^{13} \mathrm{C}$ values $3 \%$ more enriched than the corresponding $\mathrm{OM}$ values in the sediment (February: $-20.6 \pm 0.3 \%$ for POM and $-17.8 \pm$ $0.2 \%$ for meiobenthos; April: $-21.8 \pm 0.3 \%$ for POM and $-18.7 \pm 0.2 \%$ for meiobenthos [means $\pm \mathrm{SE}$ ]). In October, both $\mathrm{OM}$ and faunal average $\delta^{13} \mathrm{C}$ values were similar $(-18.2 \pm 0.4 \%$ for POM and $-18.4 \pm 0.2 \%$ for meiobenthos [means $\pm \mathrm{SE}$ ]).

At both stations, $\delta^{13} \mathrm{C}$ values were affected by time (Kruskal-Wallis, $\mathrm{p}=0.000$ and $\mathrm{p}=0.020$ for Stns $115 \mathrm{bis}$ and 330, respectively) and differed among meiobenthic taxa (Kruskal-Wallis, $\mathrm{p}=0.010$ and $\mathrm{p}=0.021$ for Stns 115 bis and 330, respectively), while there were no significant differences between sediment layers (Kruskal-Wallis, $\mathrm{p}=0.071$ and $\mathrm{p}=0.990$ for Stns 115bis and 330 , respectively). When the extremely depleted

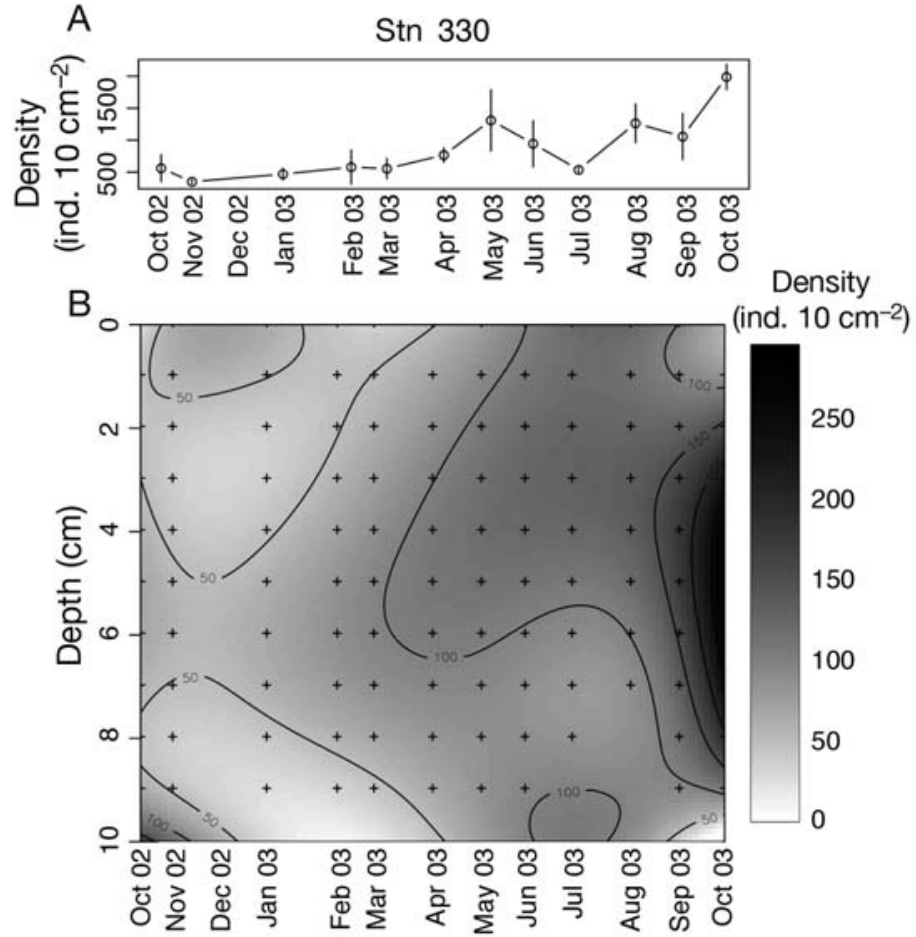

Fig. 6. Stn 330. (A) nematode densities (ind. $10 \mathrm{~cm}^{-2}$ ) from October 2002 to October 2003 summed over the vertical profile, means $\pm \mathrm{SE}_{\text {; }}(\mathrm{B})$ total nematode densities (ind. $10 \mathrm{~cm}^{-2}$ ) from 0 to $10 \mathrm{~cm}$ depth over the same time period

$\delta^{13} \mathrm{C}$ values for the copepods were excluded from the analysis for Stn $115 \mathrm{bis}, \delta^{13} \mathrm{C}$ values of the different meiobenthic taxa were no longer significantly different (Kruskal-Wallis, $p=0.081$ ), though there were significant differences among depths (Kruskal-Wallis, $p=0.027$ ).

$\delta^{15} \mathrm{~N}$ values for the meiobenthos were similar for the 2 stations (Fig. 7 and 8) and among the different meiobenthic taxa, except for the copepods at Stn 115bis in October (Fig. 7) (Kruskal-Wallis, $p=0.203$ for Stn 115bis [not including copepods] and $\mathrm{p}=0.450$ for Stn 330). For both stations, there were no significant differences in $\delta^{15} \mathrm{~N}$ between the 2 sediment layers (Kruskal-Wallis, $\mathrm{p}=0.055$ and $\mathrm{p}=0.556$ for Stns 115 bis and 330 , respectively). $\delta^{15} \mathrm{~N}$ values were not significantly affected by time at Stn 330 (Kruskal-Wallis, $p=0.053$ ) but did differ significantly over time at Stn 115bis (Kruskal-Wallis, $p=0.011$ ).

\section{DISCUSSION}

\section{Environmental variables}

As described previously (Steyaert 2003, Vanaverbeke et al. 2004a,b), chl a concentrations in the water column indicated a strong phytoplankton bloom in 
spring at both stations. The higher chl a concentrations at Stn 115bis can be explained by its position closer to the coast (Joint \& Pomroy 1993).

Although chl a concentrations in sediment also indicated a seasonal signal, considerable differences between the stations were evident. Pigment concentrations at Stn 115bis were about 5 times higher than at Stn 330 (Fig. 3 \& 4).

At the fine sandy Stn 115bis, phytodetritus accumulated near the sediment surface during spring, until mineralisation in late summer (P. Provoost et al. unpubl. data), as previously reported for other fine-sandy North Sea stations (Boon \& Duineveld 1998).

In contrast, there were no clear vertical gradients of chl a in the coarser sediments of Stn 330. Relatively strong bottom water currents can prevent the deposition of sedimenting phytodetritus at the sediment surface of permeable sediments (Huettel \& Rusch 2000). Through advective water flow, sedimenting phytoplankton cells can penetrate deeper in the sediment, inducing subsurface peaks (Huettel \& Rusch 2000, Ehrenhauss \& Huettel 2004). Such peaks occurred at Stn 330. Advective transport of oxygen into the sediment and fast removal of decomposition products (Huettel et al. 1998) accelerate POM degradation, resulting in a fast mineralisation of organic carbon and recycling of nutrients (Huettel \& Rusch 2000, Bühring et al. 2006). These processes prevent a build up of labile $\mathrm{OM}$ and the establishment of clear vertical gradients as observed in the finer sediments at Stn 115bis.

\section{Temporal patterns in meiobenthic densities}

The stations differed in nematode responses to phytoplankton deposition. A fast increase in density at Stn 330 coincided with sedimentation of labile OM from the water column. Highest densities of ca. 600 ind. $10 \mathrm{~cm}^{-2}$ were also reported in May 1999 at the same station (Vanaverbeke et al. 2004b); however, sampling only lasted until summer and there are no data in this earlier study (op. cit.) on the further responses of nematodes to late summer blooms (if present). This increase in nematode abundance was largely attributable to a rapid increase in densities of short and stout nematodes (Vanaverbeke et al. 2004a). These nematodes belong to the selective deposit feeder category sensu Wieser (1953), which has bacteria as an important food source (Moens \& Vincx 1997). The rapid incorporation of algal biomass into bacterial biomass in these sediments (Bühring et al. 2006) allows this opportunistic response in the nematode communities, whose densities were correlated with chl a concentrations in the sediment. Moreover, there was an increase in nematode densities after each deposition event in our study, indicating rapid and independent

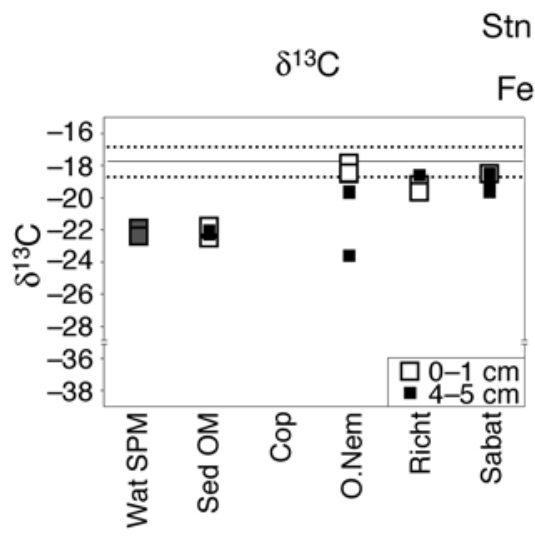

Stn 115bis

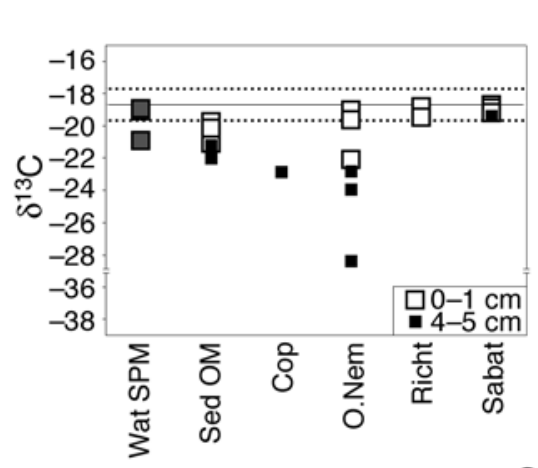

April

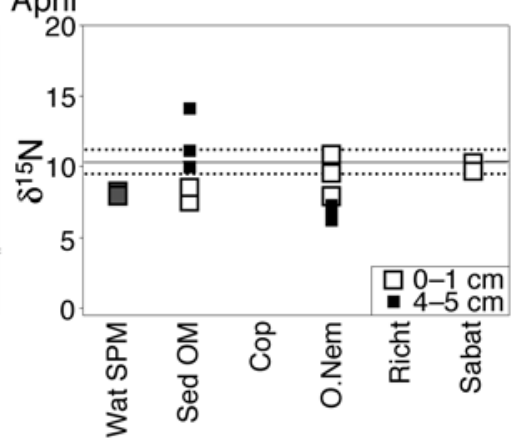

October

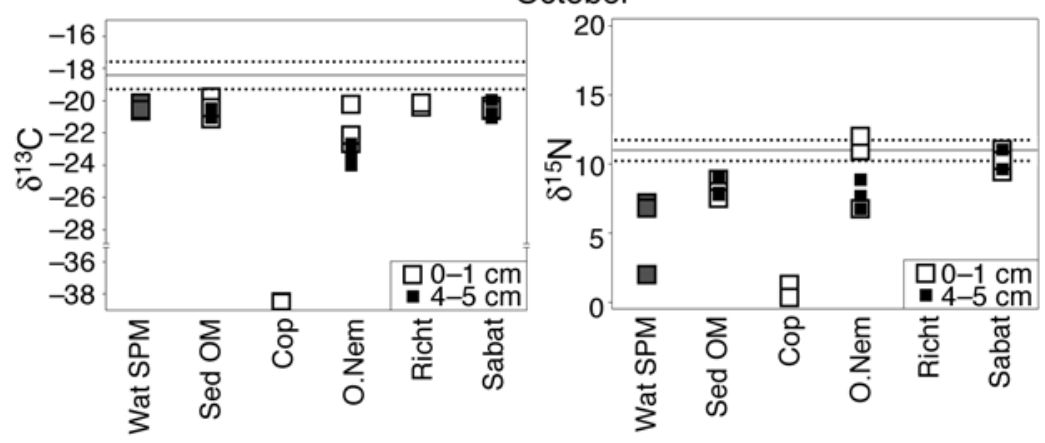

Fig. 7. Stn 115 bis. $\delta^{13} \mathrm{C}$ and $\delta^{15} \mathrm{~N}$ signatures for February, April and October 2003 from suspended particulate matter (SPM) in the water (1 $\mathrm{m}$ above the floor, $\square)$, in organic matter (OM) in the sediment, and in different meiobenthic groups at $0-1 \mathrm{~cm}$ and at $4-5 \mathrm{~cm}$ depth. $330 ; \cdots \cdots \cdot$ : SD on either side of mean of animals from station 330. Cop: copepods; O.Nem: other nematodes; Richt: Richtersia; Sabat: Sabatieria 


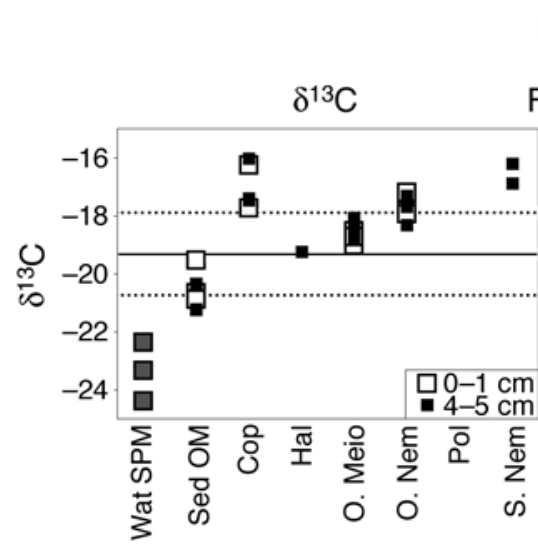

$\operatorname{Stn} 330$
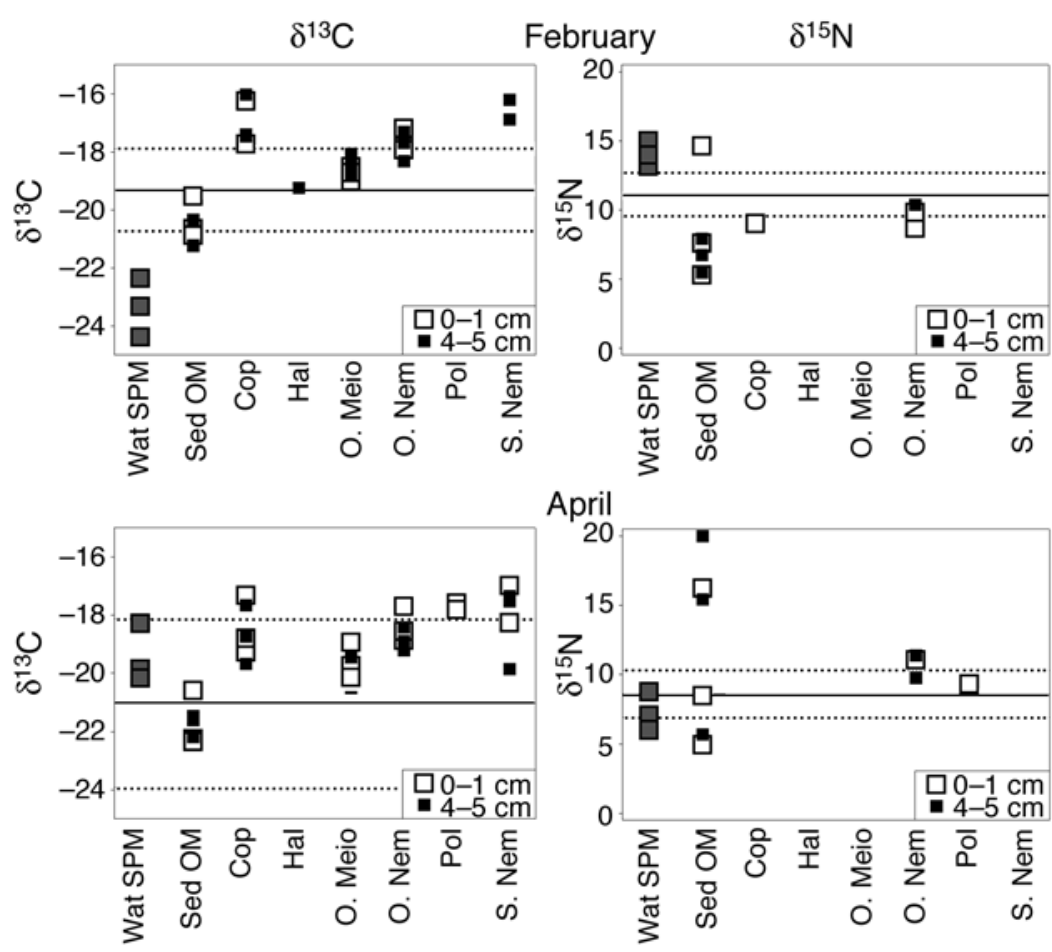

April

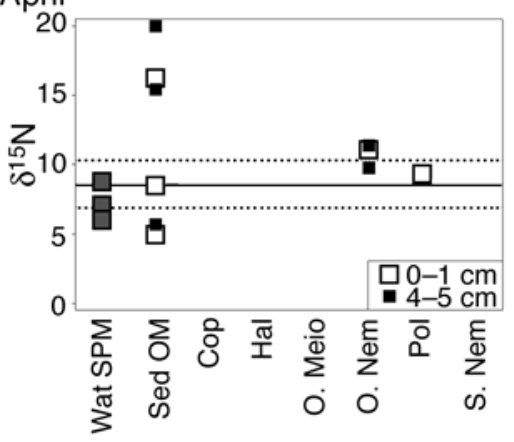

October
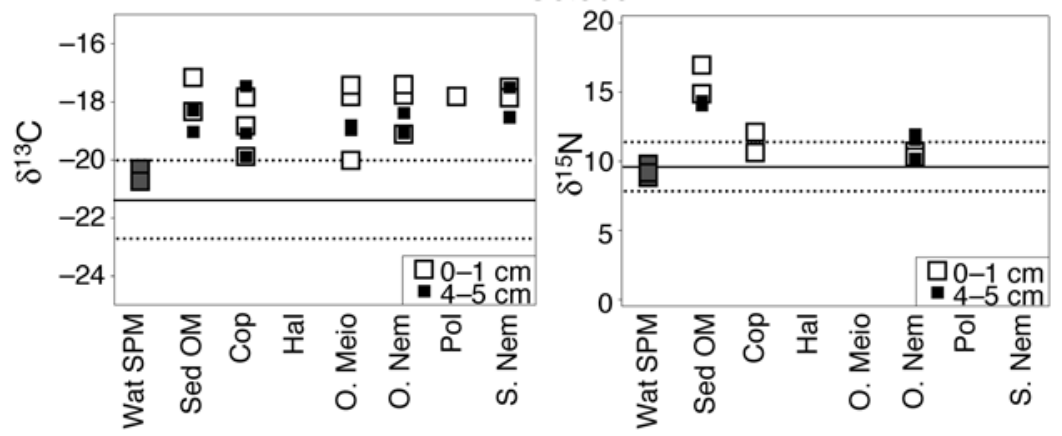

Fig. 8. Stn 330. $\delta^{13} \mathrm{C}$ and $\delta^{15} \mathrm{~N}$ signatures for February, April and October 2003 from SPM in the water (1 $\mathrm{m}$ above the floor, $\square$ ), in OM in the sediment and in different meiobenthic groups at $0-1 \mathrm{~cm}$ and at $4-5 \mathrm{~cm}$ depth. mean of animals from station 115bis (excluding copepods in October); .......: SD on either side of mean of animals from station 115bis (excluding copepods in October). Cop: copepods; Hal: Halacaroidea; O.Meio: other meiobenthos; O.Nem: other nematodes; Pol: polychaetes; S.Nem: stout nematodes

responses by the nematode community after each event. At Stn 330, the significant differences in the vertical distribution of nematodes in the upper $5 \mathrm{~cm}$ were probably the result of an upward migration of the animals towards their food source (Vanaverbeke et al. 2004b). There were no significant differences in nematode densities when we included all sediment layers in the analysis. There is no obvious explana- tion for this observation, but we suggest that it may be attributable to the continually low densities of nematodes at greater depths in this station.

In contrast, there were no significant differences in total nematode densities or vertical distributions in the upper $5 \mathrm{~cm}$ the of finer sediments at Stn 115bis, although sedimentation of phytodetritus clearly occurred. The lower densities in the sediment layers below $5 \mathrm{~cm}$ depth are the main reason why significant differences in densities among depths were found when when we included the entire sediment column in the split-plot ANOVA. However, time of sampling and the interaction term were not significant in this analysis either. In these finer grained sediments, peak mineralisation of newly arrived OM is delayed until summer (Boon et al. 1998, P. Provoost et al. unpubl. data) allowing a more gradual but extended increase in nematode densities. This may explain why there was no correlation between total nematode densities and chl $a$ at this station. There was also a gradual increase in nematode densities following the phytoplankton bloom of 1999 at the same station, with a first peak in April (ca. 2500 ind. $10 \mathrm{~cm}^{-2}$ ) and highest densities in July (slightly above 4000 ind. $10 \mathrm{~cm}^{-2}$ ) (Steyaert 2003). At both stations, nematode densities were lower in 1999 than in 2003; however, seasonal changes were similar.

The absence of clear temporal trends in the vertical distribution of the nematode community as a whole was previously reported for Stn 115bis (Steyaert 2003). However, vertical distribution patterns of dominant taxa did show speciesspecific temporal patterns that were related to food source partitioning among the dominant nematode species (Steyaert 2003). Sabatieria celtica and S. punctata, which were the dominant species during periods of low food availability, increased rapidly in density shortly after the arrival of fresh food. Both species concentrated at the sediment surface during that period. In May and June, higher densities of Daptonema riemanni and D. fistulatum, respectively, were encountered at greater depths. This coincided with the decomposition and burial of the fresh OM, triggering a seasonally-timed reproduction (Steyaert 2003). 


\section{Carbon and nitrogen stable isotope signatures}

The $\delta^{13} \mathrm{C}$ values of sediment POM were within the range reported in other studies in the Schelde estuary (The Netherlands) and in Tokachi (Japan) (Moens et al. 2002, Moens et al. 2005, Usui et al. 2006). Marine phytoplankton $\delta^{13} \mathrm{C}$ values can vary from -30 to $-18 \%$, but they are typically near $-22 \%$ (Boutton 1991). Middelburg \& Nieuwenhuize (1998) reported $\delta^{13} \mathrm{C} \approx-18 \%$ and $\delta^{15} \mathrm{~N} \approx 9 \%$ for OM of marine origin in the Schelde estuary (The Netherlands), which is located less than $100 \mathrm{~km}$ from our study area. Megens et al. (2001) observed that $\delta^{13} \mathrm{C}$ values in POM from the North Sea were more enriched in ${ }^{13} \mathrm{C}$ in spring and summer when the samples corresponded almost exclusively to fresh phytoplankton; most depleted $\delta^{13} \mathrm{C}$ values occurred in winter. At both of our stations, SPM $\delta^{13} \mathrm{C}$ values were most depleted in February (winter) and the most enriched values occurred in April during the spring phytoplankton bloom. This pattern was reflected in sediment POM at Stn 115bis, while at Stn 330 sediment POM $\delta{ }^{13} \mathrm{C}$ values changed regardless of changes in SPM, probably as a consequence of the high permeability of the sediment. During spring blooms in 2 locations in the North Sea, Phaeocystis had $\delta^{13} \mathrm{C}$ values of $-17.5 \%$ o $( \pm 0.3$; analytical error) (Van Dongen et al. 2002), which were more enriched than those in SPM in April at both stations, probably due to the mixture of Phaeocystis with other OM present in the water.

At Stn 115bis in April, more enriched POM $\delta^{13} \mathrm{C}$ values were observed in the sediment surface than in the 4 to $5 \mathrm{~cm}$ layer, indicating sedimentation of phytodetritus. In October, POM $\delta^{13} \mathrm{C}$ values in both sediment layers became more similar, probably as a result of downward transport and mineralisation during summer and late summer (P. Provoost et al. unpubl. data). At the coarser grained Stn 330, vertical differences in $\delta^{13} \mathrm{C}$
POM values were less evident, probably as a result of the permeability of the sediment, which hindered the vertical separation of fresh and older OM (Huettel et al. 1998).

Since data on isotopic signals of meiobenthic organisms from shallow subtidal habitats are presently unavailable, we compared our results with those obtained from intertidal areas and from the Antarctic deep sea (Table 1). Our $\delta^{13} \mathrm{C}$ signals in the meiobenthos were generally more depleted than previously reported for intertidal sediments (with the exception of Carman \& Fry 2002 and Riera \& Hubas 2003). However, nematodes ranged from only -16 to $-13 \%$ in the study by Carman \& Fry (2002). All these studies were conducted in intertidal habitats where microphytobenthos is common and $\delta^{13} \mathrm{C}$ values more enriched $(\approx-15 \%$, Currin et al. 1995 Moens et al. 2005) than marine phytoplankton (see above). Because intertidal meiobenthos feeds on microphytobenthos (Moens \& Vincx 1997), these primary consumers will have $\delta^{13} \mathrm{C}$ values that are more enriched than those of organisms dependent solely on water column-derived OM or its degradation products. Moens et al. (2007) reported that nematode $\delta^{13} \mathrm{C}$ values were generally more depleted in the Antarctic deep sea (130 to $2021 \mathrm{~m}$ ) than those we observed (Table 1). However in the Antarctic deep sea, POM $\delta^{13} \mathrm{C}$ values ( -24 to $-23 \%$ ) were also generally more depleted than those we observed.

Even though $\delta^{13} \mathrm{C}$ values of meiobenthos at both stations changed significantly with time, these changes did not reflect the changes in sediment POM or water SPM. Excluding copepods and deep-dwelling 'other nematodes' from Stn 115bis (discussed below), the meiobenthic $\delta^{13} \mathrm{C}$ signals at both stations varied little over time (when compared to water SPM and sediment POM) and differed little between stations $(-18.81 \pm 0.18 \%$ o, $-19.48 \pm 0.34 \%$ o and $-20.82 \pm 0.26 \%$ o

Table 1. Natural stable carbon isotope signatures of meiobenthos. Nem: Nematodes; Cop: Copepoda; Ost: Ostracoda; Hal: Halacaroidea; Pol: Polychaeta; O.Meio: Other meiobenthos; BCS: Belgian Continental Shelf. a: Couch (1989); b: Riera et al. (1996); C: Carman \& Fry (2002) ; d: Moens et al. (2002); e: Riera \& Hubas (2003); f: Moens et al. (2005); g: Steyaert et al. (2007); h: Moens et al. (2007); i: Present study.

\begin{tabular}{|c|c|c|c|c|}
\hline Location & Habitat & Meiobethic taxa & $\delta^{13} \mathrm{C}(\%)$ & Source \\
\hline $\begin{array}{l}\text { North Inlet Estuary, } \\
\text { Georgetown, USA }\end{array}$ & Intertidal mudflat & Nem, Cop & -15.83 to -13.87 & $\mathrm{a}$ \\
\hline Bay of Marennes-Oléron, France & Intertidal mudflat & Nem & -16.4 to -15.3 & $\mathrm{~b}$ \\
\hline Gulf of Mexico, USA & Salt marsh mudflat & Nem, Cop, Ost & -25 to -13 & $\mathrm{c}$ \\
\hline Schelde estuary, Netherlands & Saltmarsh, tidal flats & Nem & -18.48 to -14.03 & $\mathrm{~d}$ \\
\hline Roscoff Aber Bay, France & Intertidal sediments & Nem & -27.0 to -14.8 & e \\
\hline Schelde estuary, The Netherlands & Intertidal flat & Nem & -16.5 to -12.5 & f \\
\hline Schelde estuary, Netherlands & Intertidal mudflat & 5 Nem spp. & $\begin{array}{l}-17.9 \text { to }-12.8(3 \mathrm{spp} .) \\
-34.0 \text { to }-31.8(2 \mathrm{spp} .)\end{array}$ & $g$ \\
\hline Weddell Sea, Antarctic & Deep-sea & Nem & -27.9 to -19.3 & $\mathrm{~h}$ \\
\hline North Sea, BCS & Shallow subtidal & $\begin{array}{l}\text { Nem, Cop, Hal, } \\
\text { Pol, O.Meio }\end{array}$ & -38.54 to 16.02 & $\mathrm{i}$ \\
\hline
\end{tabular}


in February, April and October, respectively, at Stn 115bis; $-17.76 \pm 0.21 \%$, $-18.67 \pm 0.21 \%$ and $-18.45 \pm 0.18 \%$ in February, April and October, respectively, at Stn 330; means \pm SE). If there were significant changes in their $\mathrm{C}$-sources throughout the year, these were not reflected in the $\delta^{13} \mathrm{C}$ signatures.

In mesocosm experiments lasting for 5 or 6 mo, meiobenthic taxa showed preference for fresh detritus, even when not responding quantitatively to the OM input (Rudnick 1989, Widbom \& Frithsen 1995). For the period we studied in the North Sea, meiobenthic feeding preferences also remained relatively constant. Meiobenthic organisms were feeding selectively, as previously proposed Moens et al. (2007) for the Arctic deep sea.

At Stn 115bis in October, the copepods had $\delta^{13} \mathrm{C}$ values of -38.53 and $-38.54 \%$ that deviated considerably from other meiobenthic signatures. Similar $\delta^{13} \mathrm{C}$ signatures were found in macrobenthos carrying symbiotic sulphur-oxidising chemoautotrophic bacteria or having chemosynthesis-based nutrition (e.g. Tsutsumi et al. 2001, Levin \& Michener 2002). Chemoautotrophic bacteria generate organic molecules from $\mathrm{CO}_{2}$ and obtain required energy by oxidation of reduced inorganic substrates (Fenical \& Jensen 1993). The $\delta^{13} \mathrm{C}$ signal of the copepods from Stn 115bis indicates exploitation of a chemosynthetically-derived food resource. Similar $\delta^{13} \mathrm{C}$ signatures have been reported for a nematode species at the Håkon Mosby Mud Volcano, which is dominated by sulphidic microbial mat sediments in a cold methane-venting seep (Van Gaever et al. 2006). Moens et al. (2007) obtained a $\delta^{13} \mathrm{C}$ signal of $-34.6 \%$ for a single nematode sample in the Antarctic deep sea; this was attributed to a possible consumption of chemosynthetic bacteria by the animals.

Sediments at Stn 115bis were generally reduced during spring 1999 (Steyaert 2003) and during our sampling period (authors' unpubl. data based on oxygen penetration depth data), and thus may contain sulphur-oxidising bacteria. Levin \& Michener (2002) observed for some chemosynthetic bacterial mats an average $\delta^{15} \mathrm{~N}$ of $-1.50 \%$. A consumer feeding on bacteria with such a $\delta^{15} \mathrm{~N}$ value would have a signature $3.4 \%$ more enriched (Post 2002), bringing it close to the values we observed for copepods from Stn 115bis in October. This suggests that these copepods were indeed exploiting a chemosynthetic food source.

The specificity of copepods from Stn 115bis in October for such a food source indicates its importance, at least in a specific period of time. To our knowledge, such a clear indication of exploitation of a chemosynthetically-derived food source by meiobenthic organisms (other than in cold seeps) has been previously reported only for 2 nematode species from intertidal sediments (Steyaert et al. 2007), and our study pro- vides the first evidence of such exploitation in shallow subtidal sediments. Even though it can be an important food source, at least in a certain time period, its relevance for meiobenthic organisms remains unknown.

When copepod values were excluded from the analysis of Stn 115bis, meiobenthic $\delta^{13} \mathrm{C}$ signatures differed significantly by depth. Rudnick (1989) suggested the existence of 2 distinct depth-segregated food webs for meiobenthic organisms in muddy sediments. Among the meiobenthic taxa, 'other nematodes' had the strongest vertical differences in $\delta^{13} \mathrm{C}$ values, especially in April. Species belonging to the genus Sabatieria (e.g. S. celtica and S. punctata) are known to migrate towards their food sources, while other dominant species belonging to other abundant genera (e.g. Daptonema riemanni and D. fistulatum) are restricted to deep sediment horizons (Steyaert 2003). The more depleted $\delta^{13} \mathrm{C}$ values in deepdwelling 'other nematodes' species indicate the existence of vertically-segregated food webs, with deepdwelling nematodes exploiting separate carbon sources. It is also possible that, as with the copepods, some deep-dwelling 'other nematodes' species were exploiting a chemosynthetically derived food source as well. However, this may be restricted to a few nematode species and their more depleted signal would therefore be diluted.

At Stn 330, there were no vertical differences within the meiobenthic $\delta^{13} \mathrm{C}$ values or in POM. This probably resulted from the permeable nature of the sediment, which inhibits the build up of vertical gradients in POM quality and quantity. However the stout nematodes, which showed the strongest response to phytodetritus deposition at this station (Vanaverbeke et al. 2004a), had $\delta^{13} \mathrm{C}$ values that were similar to other nematodes, copepods and polychaetes. Hence, our results do not indicate differences in carbon sources and/or feeding strategy. Stout and short nematodes can become dominant during certain periods of time and/or areas with permeable sediments and almost absent in others (Vanaverbeke et al. 2004a; UrbanMalinga et al. 2006). What life cycle feature makes these stout and short nematodes such successful colonizers is not yet known.

Except for the copepods at Stn 115bis in October 2003, there were no significant $\delta^{15} \mathrm{~N}$ differences between the different meiobenthic groups at either station. $\delta^{15} \mathrm{~N}$ values similar to ours for nematodes have been reported in the Bay of Marennes-Oléron and in Roscoff Aber Bay, France, ranging from 8.9 to $9.3 \%$ and from 9 to $14.3 \%$, respectively (Riera et al. 1996; Riera \& Hubas 2003). Slightly more depleted values than those we observed (ranging from ca. 3 to $8 \%$ ) occurred in the North Inlet Estuary, Georgetown and in the Gulf of Mexico, USA, respectively (Couch 1989; 
Carman \& Fry 2002). The more enriched $\delta^{15} \mathrm{~N}$ values reported by Moens et al. (2005) for the Schelde estuary (reaching values of $20 \%$ ) correspond the predatory feeding of the respective species. These species, if present in our samples, would be found within the 'other nematodes'. Even though the relative importance of their signal depends on the relative biomass of such consumers (for which we have no information), predators are generally not dominant (in terms of relative densities) within the nematodes at the sites studied (Steyaert 2003, Vanaverbeke et al. 2004b), so it is likely that their signature would be diluted in the 'other nematodes' signature.

In conclusion, the nematode community responses to the deposition of the phytoplankton bloom differed by the biogeochemical nature of the sediment; in fine sediments the prolonged presence of OM resulted in a gradual response of the nematode community, with highest densities long after the deposition of phytodetritus. Depth-related differences in food-webs and feeding strategies occurred in these sediments. In permeable sediments, OM reaching the sediment was quickly mineralised and the whole system responded quickly. The genus Sabatieria's ability to migrate towards a food source may be the reason for its success, being able to respond opportunistically to an OM input. On the other hand, stout nematodes showed no differences from other nematodes as initially expected. In general, the meiobenthic ${ }^{13} \mathrm{C}$ signatures remained similar over time and were not coupled with changes in the water and sediment OM, indicating selective feeding.

Acknowledgements. We thank the master and crew of the RV 'Belgica' and 'Zeeleeuw' for their skilful help during sampling. We acknowledge L. Moodley for help in setting up the project and for commenting on an earlier version of the manuscript. This research was funded by the Belgian Science Policy (TROPHOS - Contract nr. EV/02/25A). UGENT-BOF project 01GZ0705 Biodiversity and Biogeography of the Sea (BBSea) (2005-2010). M.A.F. was financially supported by a PhD grant from the Foundation for Science and Technology (FCT - SFRH/BD/10386/2002). Three anonymous reviewers and L. Levin greatly improved the quality of the manuscript. The authors acknowledge the support by the MarBEF Network of Excellence 'Marine Biodiversity and Ecosystem Functioning' which is funded by the Sustainable Development, Global Change and Ecosystems Programme of the European Community's Sixth Framework Programme (contract no. GOCE-CT-2003-505446). This publication is contribution number MPS-07092 of MarBEF. This is publication 4219 of the Netherlands Institute of Ecology (NIOO-KNAW), Yerseke.

\section{LITERATURE CITED}

Boon AR, Duineveld GCA (1998) Chlorophyll a as a marker for bioturbation and carbon flux in southern and central North Sea sediments. Mar Ecol Prog Ser 162:33-43

Boon AR, Duineveld GCA, Berghuis EM, Van der Weele JA (1998) Relationships between benthic activity and the annual phytopigment cycle in near-bottom water and sediments in the southern North Sea. Estuar Coast Shelf Sci 46:1-13

Boutton TW (1991) Stable carbon isotope ratios of natural materials: II. Atmospheric, terrestrial, marine, and freshwater environments. In: Coleman DC, Fry B (eds) Carbon isotopes techniques. Academic Press, San Diego, CA, p 173-185

Bühring SI, Ehrenhauss S, Kamp A, Moodley L, Witte U (2006) Enhanced benthic activity in sandy sublittoral sediments: evidence from ${ }^{13} \mathrm{C}$ tracer experiments. Mar Biol Res 2: 120-129

Carman KR, Fry B (2002) Small-sample methods for $\delta^{13} \mathrm{C}$ and $\delta^{15} \mathrm{~N}$ analysis of the diets of marsh meiofaunal species using natural-abundance and tracer-addition isotope techniques. Mar Ecol Prog Ser 240:85-92

$>$ Couch CA (1989) Carbon and nitrogen stable isotopes of meiobenthos and their food resources. Estuar Coast Shelf Sci 28:433-441

Currin CA, Newell SY, Paerl HW (1995) The role of standing dead Spartina alterniflora and benthic microalgae in salt marsh food webs: considerations based on multiple stable isotope analysis. Mar Ecol Prog Ser 121:99-116

- Ehrenhauss S, Huettel M (2004) Advective transport and decomposition of chain-forming planktonic diatoms in permeable sediments. J Sea Res 52:179-197

Fenical W, Jensen PR (1993) Marine microorganisms: a new biomedical resource. In: Attaway DH, Zaborsky OR (eds) Marine biotechnology: Vol 1. Pharmaceutical and bioactive natural products. Springer, New York, p 419-458

Franco MA, De Mesel I, Demba Diallo M, Van der Gucht K and others (2007) Effect of phytoplankton bloom deposition on benthic bacterial communities in two contrasting sediments in the southern North Sea. Aquat Microb Ecol 48:241-254

Graf G (1992) Benthic-pelagic coupling-a benthic view. Oceanogr Mar Biol Annu Rev 30:149-190

Heip C, Vincx M, Vranken G (1985) The ecology of free-living nematodes. Oceanogr Mar Biol Annu Rev 23:399-489

Huettel M, Rusch A (2000) Transport and degradation of phytoplankton in permeable sediment. Limnol Oceanogr 45:534-549

Huettel M, Ziebis W, Forster S, Luther GW (1998) Advective transport affecting metal and nutrient distributions and interfacial fluxes in permeable sediments. Geochim Cosmochim Acta 62:613-631

Joint I, Pomroy A (1993) Phytoplankton biomass and production in the southern North-Sea. Mar Ecol Prog Ser 99: 169-182

Levin LA, Michener RH (2002) Isotopic evidence for chemosynthesis-based nutrition of macrobenthos: the lightness of being at Pacific methane seeps. Limnol Oceanogr 47: 1336-1345

Megens L, Van der Plicht J, de Leeuw JW (2001) Temporal variations in ${ }^{13} \mathrm{C}$ and ${ }^{14} \mathrm{C}$ concentrations in particulate organic matter from the southern North Sea. Geochim Cosmochim Acta 65:2899-2911

Middelburg JJ, Nieuwenhuize J (1998) Carbon and nitrogen stable isotopes in suspended matter and sediments from the Schelde Estuary. Mar Chem 60:217-225

Middelburg JJ, Barranguet C, Boschker HTS, Herman PMJ, Moens T, Heip CHR (2000) The fate of intertidal microphytobenthos: an in situ ${ }^{13} \mathrm{C}$-labeling study. Limnol Oceanogr 45:1224-1234

Moens T, Vincx M (1997) Observations on the feeding ecology of estuarine nematodes. J Mar Biol Assoc UK 77:211-227

Moens T, Luyten C, Middelburg JJ, Herman PMJ, Vincx M (2002) Tracing organic matter sources of estuarine tidal 
flat nematodes with stable carbon isotopes. Mar Ecol Prog Ser 234:127-137

Moens T, Bouillon S, Gallucci F (2005) Dual stable isotope abundances unravel trophic position of estuarine nematodes. J Mar Biol Assoc UK 85:1401-1407

Moens T, Vanhove S, De Mesel I, Kelemen B, Janssens T, Dewicke A, Vanreusel A (in press) Carbon sources of Antarctic nematodes as revealed by natural carbon isotope ratios and a pulse-chase experiment. Polar Biol 31:1-13

Post DM (2002) Using stable isotopes to estimate trophic position: models, methods, and assumptions. Ecology 83: $703-718$

Riera P, Hubas C (2003) Trophic ecology of nematodes from various microhabitats of the Roscoff Aber Bay (France): importance of stranded macroalgae evidenced through $\delta^{13} \mathrm{C}$ and $\delta^{15} \mathrm{~N}$. Mar Ecol Prog Ser 260:151-159

Riera P, Richard P, Gremare A, Blanchard G (1996) Food source of intertidal nematodes in the Bay of MarennesOleron (France), as determined by dual stable isotope analysis. Mar Ecol Prog Ser 142:303-309

Rudnick DT (1989) Time lags between the deposition and meiobenthic assimilation of phytodetritus. Mar Ecol Prog Ser 50:231-240

Steyaert M (2003) Spatial and temporal scales of nematode communities in the North Sea and Westerschelde. PhD Thesis, Ghent University, Ghent

Steyaert M, Herman PMJ, Moens T, Widdows J, Vincx M (2001) Tidal migration of nematodes on an estuarine tidal flat (the Molenplaat, Schelde Estuary, SW Netherlands). Mar Ecol Prog Ser 244:299-304

Steyaert M, Moodley L, Nadong T, Moens T, Soetaert K, Vincx M (2007) Responses of intertidal nematodes to short-term anoxic events. J Exp Mar Biol Ecol 345:175-184

Tsutsumi H, Wainright S, Montani S, Saga M, Ichihara S, Kogure K (2001) Exploitation of a chemosynthetic food resource by the polychaete Capitella sp I. Mar Ecol Prog Ser 216:119-127

Urban-Malinga B, Hedtkamp SIC, Van Beusekom JEE,

Editorial responsibility: Lisa Levin,

La Jolla, California, USA
Wiktor J, Weslawski JM (2006) Comparison of nematode communities in Baltic and North Sea sublittoral, permeable sands - diversity and environmental control. Estuar Coast Shelf Sci 70:224-238

Usui T, Nagao S, Yamamoto M, Suzuki K and others (2006) Distribution and sources of organic matter in superficial sediments on the shelf and slope off Tokachi, western North Pacific, inferred from $\mathrm{C}$ and $\mathrm{N}$ stable isotopes and C/N ratios. Mar Chem 98:241-259

Van Dongen BE, Schouten S, Damste JSS (2002) Carbon isotope variability in monosaccharides and lipids of aquatic algae and terrestrial plants. Mar Ecol Prog Ser 232:83-92

Van Gaever S, Moodley L, de Beer D, Vanreusel A (2006) Meiobenthos at the Arctic Håkon Mosby Mud Volcano, with a parental-caring nematode thriving in sulphide-rich sediments. Mar Ecol Prog Ser 321:143-155

> Vanaverbeke J, Soetaert K, Vincx M (2004a) Changes in morphometric characteristics of nematode communities during a spring phytoplankton bloom deposition. Mar Ecol Prog Ser 273:139-146

> Vanaverbeke J, Steyaert M, Soetaert K, Rousseau V, Van Gansbeke D, Parent JY, Vincx M (2004b) Changes in structural and functional diversity of nematode communities during a spring phytoplankton bloom in the southern North Sea. J Sea Res 52:281-292

Widbom B, Frithsen JB (1995) Structuring factors in a marine soft bottom community during eutrophication-an experiment with radio-labeled phytodetritus. Oecologia 101: $156-168$

Wieser W (1953) Die Beziehung zwischen Mundhöhlengestalt, Ernährungsweise und Vorkommen bei freilebenden marinen Nematoden. Ark Zool 2:439-484

Wright SW, Jeffrey SW (1997) High-resolution HPLC system for chlorophylls and caretenoids of marine phytoplankton. In: Jeffrey SW, Mantoura RFC, Wright SW (eds) Phytoplankton pigments in oceanography: guidelines to modern methods. UNESCO, Paris, p 327-341

Submitted: March 13, 2007; Accepted: November 29, 2007 Proofs received from author(s): March 25, 2008 